\title{
The venturous bid for the independence of Catalonia
}

\author{
Josep M. Colomer* \\ Department of Government, Georgetown University, 588 ICC, 3700 O Street, NW, Washington,
} DC 20057, USA

(Received 8 April 2016; accepted 19 October 2016)

\begin{abstract}
Following an ambiguous constitutional compromise for democratization, the territorial decentralization of the Spanish state developed by means of political party competition, exchanges, and bargaining. Hence, the so-called state of autonomies was characterized as "non-institutional federalism" [Colomer, Josep M. 1998. "The Spanish 'State of Autonomies': Non-institutional Federalism." West European Politics 21 (4): 40-52]. In the most recent period, competition and instability have intensified. New developments include, on one side, attempts at recentralizating the state and, on the other side, demands and mobilizations for Catexit, that is, the independence of Catalonia from Spain, which resulted in sustained inter-territorial conflict. This article addresses these recent changes with a focus on the relations between the Spanish and the Catalan governments. The political changes were analyzed as a result of opportunities and incentives offered by a loose institutional framework and the subsequent competitive strategies of extreme party leaders.
\end{abstract}

Keywords: federalism; secession; nationalism; European Union; Spain; Catalonia

\section{Introduction}

Since the beginning of the twenty-first century, relations between Catalonia and the Spanish state have developed in increasing levels of conflict. The so-called Spanish "state of autonomies" was not a stable institutional solution but a loose setting for competition among political parties and territorial governments, which eventually created incentives for launching a secessionist venture. In contrast to other interpretations, I hold in this article that the bid for the independence of Catalonia was not a response of Catalan politicians to people's demands, but an elite-driven, politically motivated strategy endogenous to the political process of sustained and increasing confrontation with the Spanish government.

Specifically, the pro-independence process originated in vintage ambitions of partisan politicians of the Republican Left of Catalonia (ERC) and some members of the Democratic Convergence of Catalonia (CDC). It took advantage of exclusionary features of Spanish democracy and low levels of institutionalization of the "state of autonomies." It was accelerated by the social distortions created by the economic crisis that exploded in 2008 and it produced increasing radicalization of some parties and high polarization and the eventual collapse of the party system of Catalonia. All in all, the process ruined the existing autonomy, but it was not able to impose an alternative formula.

\footnotetext{
*Email: colomerj@georgetown.edu
} 
The problem is long-standing. The country called Spain has always had weak national cohesion. Spain had an early, great, costly empire, which depleted the crown of its already scarce resources and left the modern Spanish state relatively weak. The subsequent building of a culturally unified Spanish nation was an unconcluded venture. In particular, the Spanish state and nation was too weak to integrate large portions of the Catalan and Basque populations into unitary and centralized structures and a Castile-dominated single cultural pattern. The territorial differences were strengthened by the early industrialization of the peripheral Northern Catalonia and Basque Country. Yet the Spanish state has been sufficiently strong to prevent Catalonia and the Basque Country from building alternative nations and states (Prados de la Escosura 1988; Carreras and Tafunell 2004; Ucelay-Da Cal 2014).

Seen from the other side: the Catalan and Basque societies have been sufficiently differentiated to resist a unilateral Spanish assimilation, but too weak to build their own unified nations. This type of countervailing relation of forces without a clear winner is the perfect situation for a stalemate.

Given the sustained differences between economic structures, the majority Castilian language and cultural patterns, and the Catalan, Basque, and Galician ones, Spain has been typified as a multinational state (Rokkan 1971; Linz 1973, 1975; Colomer 2008a). At the same time, Catalonia, as well as the Basque country and other communities to some extent are bi-national societies, as they are partly shaped by Castilian assimilation and partly by persistent resistance and new initiatives and nationalist developments. The Spanish state can be seen as containing a set of uncompleted nations that have developed themselves in mutual rivalry, rather than within a cooperative institutional setting. These mixtures are likely to endure, as reinforcing the sovereignty of the states and building more homogeneous nations have become implausible projects within the current European Union (EU) and in an increasingly interdependent world.

When the Generality of Catalonia was reestablished in 1977, a new Statute of Autonomy was approved in 1979 and the first election to the parliament of Catalonia was held in 1980; Spain was not yet a member of the EU. The main aim of the Catalan governments formed by the nationalist coalition Convergence and Union (CiU), led by Jordi Pujol, was then the building of a more homogeneous Catalan nation within the Spanish state. A main priority was a language policy that favored Catalan in public administration and public media and established monolingual immersion in Catalan in all public and private schools.

For two decades, Catalan politics involved centripetal electoral competition, as nationalists were seeking to build "a cornerstone" or "to string together the scattered cards" of Catalan society. The Catalan government largely saw the political autonomy of Catalonia and its exchanges of parliamentary support with Spanish governments as instruments for the main goal of building a Catalan cultural nation. Other purposes (such as the fiscal decentralization of the state, reforming the central institutions in favor of more inclusive or accommodating formulas, enhancing the influence of the Catalan government in EU institutions, or even strengthening the institutional framework of Catalonia) were not on the agenda.

This strategy attained limited success. The Catalan language was expanded to virtually all the population of Catalonia, including the former immigrants from other regions of Spain and their children born in Catalonia. But bilingualism prevailed in actual uses. Most citizens of Catalonia consider themselves as Catalan and Spanish to some degree. Many new immigrants arrived from more distant lands. Multicultural references and relations proliferated through new media and transnational communication networks. 
The main change in Catalan politics since the turn of the century was a switch from nation-building to state-building, that is, the replacement of the priority to culture with a focus on institutions. This is consistent with the premise that nations, as they can be conceived as standardized and relatively homogeneous cultural communities, are created by existing states or state-like institutions, rather than previously existing nations creating states. This new focus develops, nevertheless, in modern Europe, where "there is nowhere a complete fit between the 'state' and the "nation"" (Rokkan 1971; further discussed by Eisenstadt and Rokkan 1973; Linz 1973, 1993; Tilly 1975; Rokkan and Urwin 1983; Colomer 2008a).

In the new institutionalist orientation, first, the "Catalanist and leftist government," initially chaired by Pasqual Maragall of the Party of the Socialists of Catalonia (PSC), aimed at strengthening Catalan self-rule within a federal Spain. Priority was given to a new political Statute of Catalonia and to reshaping the institutions of the Spanish state. This strategy clashed with strong resistance to reform from Spanish central institutions.

Disillusionment with Spain among the population increased considerably during a period in which the country suffered a huge economic and political crisis. The new Catalan governments chaired by Artur Mas initially explored a further fiscal decentralization of the state. But they soon sensed that Spain could not be reformed and targeted the sovereignty and independence of Catalonia.

The announced aim of the most recent Catalan governments has been to build "state structures" in fields in which they do not have full autonomous powers, especially taxation, justice, and international relations, and to hold a referendum or plebiscite to declare independence unilaterally. The Catalan and the Spanish governments sustain confrontation and hostility. The elephant in the room, however, is that Catexit, that is, the secession of Catalonia from Spain, would also imply exit from the EU. As the actual sovereignty of existing member-states of the EU has vanished, the creation of new independent states from within the union is largely discarded.

Each of the Catalan demands mentioned above and the subsequent mobilizations raised high expectations. Yet all clashed with Spanish resilience and with the structural obstacles derived from increasing European and international interdependence. Every step in the process of escalation was followed by considerable frustration, which was responded to with increasing radicalization. Recently, political action for independence moved to a great extent from regular institutions to non-governmental organizations, mixed coalitions of politicians and social leaders, street mobilizations, assemblies, and referendums. The previous centripetal party system of Catalonia has been replaced with high electoral volatility, a more fragmented configuration of electoral candidacies and political groups, and polarization on nationalist and socioeconomic dimensions. Conflict, radicalization, and instability forebode a hazardous future.

The first part of the following analysis places these changes in the loose institutional framework of the Spanish state of autonomies, which permit a variety of minority winners. The second part reviews how, in this propitious institutional setting, extreme parties have manipulated the public agenda and promoted confrontational positions.

\section{Disjoined battlefields}

We begin reviewing the institutional and organizational framework of the recent political process. Multiple levels of government, parties, policy dimensions, and low levels of institutionalization offer many opportunities for competitive partisan strategies. 


\section{Multi-level governments}

The citizens of Spain live under multiple political jurisdictions. They are supposed to be ruled by governments at the local, the autonomous, the state, and the European level. This multi-level institutional structure was the result of several cumulative political processes during the 1970s and 1980s that did not anticipate a whole, consistent project. Political practice is characterized by relatively low abidance by the rules, an absence of inter-institutional cooperation, and the prevalence of party competition and strategic action (Colomer 1990, 1991, 1995, 2008a).

Specifically, the territorial decentralization of the Spanish state did not derive from an explicit mandate in the 1978 Constitution. The constitutional compromise mixed contradictory elements from different political projects: the maintenance of the provinces, the reestablishment of particular governments for Catalonia, the Basque Country, and Galicia, and the introduction of a general decentralizing formula for the rest of Spain. Constitutionally, Spain is not defined as a federal state. Multiple territorial governments with different legal powers were created without adopting typical federal institutions, such as an upper chamber of territorial representation or other elements of inter-institutional cooperation. Even the usual expression "state of autonomies" or the list of autonomous communities do not appear in the constitutional text. Any mention to the EU does not appear either.

In fact, the Spanish political system has been dominated by the discretion of the main party leaders, rather than by a more automatic interplay under formal rules. The decentralization of the state, like other institutional processes, has been the result of party strategies, competition, and bargaining. The actual working of the so-called state of autonomies was named non-institutional competitive federalism (Colomer 1998). Most autonomous governments wanted to approach the level of autonomy of the Basques and the Catalans. But the Basque and the Catalan governments tried to maintain a difference from the rest of the communities. This game of rivalry among autonomous communities has usually been known as "comparative grievance." It looks like a greyhound race in which the dogs chase after the hare, which escapes and provokes acceleration of all the players. Eventually, it provoked a venturous sprint toward independence.

In the Spanish political regime, territorial decentralization has worked against many institutional elements intended to promote a concentration of powers and unified government in the center of the state. The main Catalan parties, together with other nationalists in the Basque Country, Galicia, and the Canary Islands, proved to be effective in obtaining increasing devolution, especially by trading transfers of powers for parliamentary support to Spanish governments (Field 2015).

But a strategy relying on exchanges at some opportune junctures was also vulnerable to changes in the center. By the turn of the century, rejections of further demands for more decentralization and attempts at introducing new legal and institutional restrictions reappeared. At the same time, the Spain-wide party system entered crisis, largely corroded by the excessive partisan control of the institutions, as well as by politicians' abuses and corruption. The previous exchanges of support between the parties in government in Catalonia and in Spain were replaced with sustained conflict between the two governments.

\section{Minority-winning rules}

The rivalries between territorial governments and with the central government have been fights among minorities. No party has ever won an absolute majority of votes at any Spanish or Catalan election. The basic institutional rules for government formation at state, autonomous, and local levels favor minority winners and minority rulers, which 
attract limited degrees of popular legitimization. This creates incentives for extreme parties on the nationalist and the socioeconomic dimensions to develop their initiatives without the need to create broad consensus with other parties.

All Spanish governments since 1977 were one-party governments based on the support of only a minority of the popular vote. The average electoral support of the government was $40 \%$. For nearly 40 years, Spain has been the only country in Europe where there never was a government with a majority electoral support or a multiparty coalition, two features that tend to coincide. This means that there was always a clear majority of voters that had not voted for the ruling party. The electoral support of the Spanish ruling party in Catalonia has been even lower than in the whole of Spain, with an average of only $30 \%$, which has led to the alienation of large segments of people from Spanish politics (Colomer 2008b, 2010).

The governments of Catalonia have resisted any attempt at homogenizing or harmonizing the institutional rules of the Generality with the other levels of government. But the Catalan institutions are not much more inclusive or stabilizing than those of the parliament and the government of Spain. Catalonia is the only autonomous community whose parliament has been unable to approve its own electoral law. Catalan elections are held according to a transitory disposition in the Statute of 1979 , which was conceived only for the first election (Comissio d'Experts 2007). Like the Spanish president of the government, the parliamentary investiture of the President of the Generality requires the support of only a plurality of members of parliament, short of a majority. As a result, most governments of the Generality of Catalonia since 1980 were single-party governments based on a minority of the popular vote. The average was $42 \%$.

The election of city councils is fairly proportional, as it is based on a single electoral district. But the further election of the mayor also favors minority winners. If no candidate obtains the support of a majority of councilors, the candidate of the most voted party is appointed mayor even if the party has received less than a majority of the popular vote. There have been some multiparty coalitions in mayoral teams, especially in the larger cities. In Barcelona, in particular, multiparty coalitions ruled the city after eight of 10 elections. But only four of these coalitions gathered together the support of a majority of the popular vote. The two most recent mayors of Barcelona, elected in 2011 and 2015, have had minority support from both popular votes and councilor seats.

The functioning of the EU institutions is in big contrast with the Spanish pattern of minority-supported governments at state, autonomous, and local levels, as the EU rules and works by broad consensus favoring stable policies. The European Parliament and the Commission elected by the former are driven by a super-grand multiparty coalition, which usually gathers together about two-thirds of the popular vote and of the parliamentary seats. The parliament favors aggregation in larger groups, in contrast to the fragmentation of the Spanish and Catalan representatives. All but one of the members of the European Parliament elected from seven Catalan parties in 2014 are integrated into only three larger, central European Political Groups (Colomer 2007, 2016).

\section{Two-dimensional multiparty system}

In the Spanish Congress the absolute number of parties tends to be high because it includes a few Spain-wide parties and many nationalist regional parties, but the Spain-wide parties largely dominate. The degree of pluralism is higher in Catalonia, greatly as a consequence of its more balanced bi-national structure. Spain-wide parties coexist with Catalan parties federated or stably coalesced with Spanish parties and with Catalan-only parties. 
The policy-ideology space of Catalonia in which political parties move has been understood as a two-dimensional space since the mid-1980s (Colomer 1985; Colomer and PadróSolanet 1992). Before that, both political actors and observers had been trying to collapse the political game into a single dimension, whether left-right when the political game was spotted from the left side or nationalist when it was glimpsed from the Catalan side. Since the early 1980s, the Spanish Socialist Workers' Party (PSOE) led by Felipe Gonzalez had won several consecutive Spanish elections, and the CiU led by Jordi Pujol had won several consecutive Catalan elections, which configured a Spanish-left-wing vs. Catalan-right-wing axis.

But the above-reviewed structure with multiple levels of government and the different strategies that the parties adopted to playing in such a framework were better modeled as multidimensional with the help of the spatial theory of voting (Downs 1957; Enelow and Hinich 1984). The multidimensionality of the policy space was confirmed by further victories of the right in Spain and the left in Catalonia, with further alternations also following. As we will see, more recently the political party's relative positions have almost inverted: they are increasingly polarized along a single axis which, in contrast to the appearances in the 1980s and 1990s, is left-Catalan and Spanish-right.

On both policy dimensions, the majority of voters locate themselves on non-extreme positions. On the first dimension, more than two-thirds of voters are moderate (about $32 \%$ at the center, $30 \%$ at center-left, and $8 \%$ at center-right), while about one-fifth lie on leftist positions and only $3 \%$ on rightist ones.

Analogously, on the second dimension, nearly two-thirds of voters identify themselves as bi-national (nearly 40\% feel as Catalan as Spanish, 20\% more Catalan than Spanish, and 6\% more Spanish than Catalan), while about one-fourth feel only Catalan, and 5\% only Spanish.

The average values lie at moderate center-left, 3.9 , on a scale from "extreme left" at 0 and "extreme right" at 10 with 5 at the center, and at moderate Catalan, 6.3, on a scale from "maximum Spanish" at 0 and "maximum Catalan" at 10, also with 5 at the center (surveys by Centre d'Estudis d'Opinio (CEO) 35, 36, 2015; Centro de Investigaciones Sociológicas CIS 3108, 3113, 2015a, 2015b).

Regarding the political parties, their locations in the policy space have been relatively stable for several decades. Parties have not leapfrogged or jumped over one another.

In the cited surveys, the parties are located on the first dimension, from left to right, as follows: Candidacy of Popular Unity (CUP), Initiative for Catalonia Greens-We Can (ICVPod), ERC, PSC, Citizens (C's), CDC, People's Party (PP).

On the second dimension, from Catalan to Spanish, the ordering is: ERC, CUP, CDC, ICV-Pod, PSC, Citizens (C's), PP.

The differences between the two orderings are the basis for building a two-dimensional space, as the parties could not be consistently located on a single dimension. Figure 1 offers a graphic representation of the average location of the parties by surveyed citizens in 2015 . On the left-right dimension, the parties having held the Spanish government, the PSOE and the PP, approached each other around a pro-market economy and redistributive social policies. Also, CiU and ERC declared to be liberal or social-democratic at different moments and tried to move more or less near center-left positions depending on the circumstances of electoral competition and possible parliamentary exchanges. Integration in the EU also reinforced the stability of socioeconomic policies.

There was more ambiguity on the nationalist dimension. The self-government of Catalonia was constitutionalized with a moderate formula of special autonomy, different from the common regime of most autonomous communities. But the label "Catalanism," which was accepted as a reference by virtually all parties as a common field, was supposed to be compatible with support for autonomy, federalism, sovereignty, or independence. The 


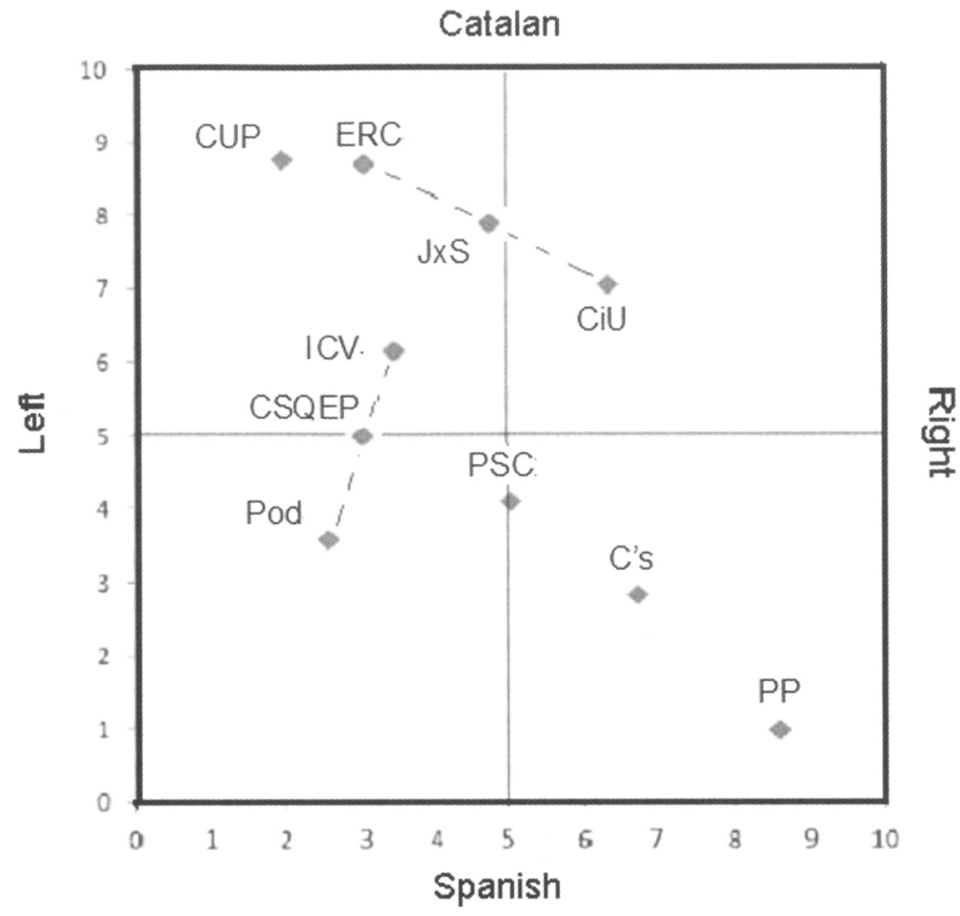

Figure 1. Political party locations on the left-right and Spanish-Catalan two-dimensional policy space. Source: Author's elaboration with data from surveys by Centre d'Estudis d'Opinio, 2015, 2016.

Note: The horizontal axis represents left-right socioeconomic policy issues; the vertical axis represents Spanish-Catalan nationalist issues. CUP: Candidacy of Popular Unity. JXS: Together for Yes: electoral coalition of CDC - Democratic Convergence of Catalonia (formerly in the federation Convergence and Union CiU), ERC - Republican Left of Catalonia, and other groups. CSQEP: Catalonia Yes We Can: electoral coalition of ICV - Initiative for Catalonia Greens, Pod - We Can, and other groups. PSC: Party of the Socialists of Catalonia. C's: Citizens. PP: People's Party.

multidimensionality of the policy space and the fuzziness of the ideological package used to cover broad segments of such a space created large room for political parties' maneuvering, as it is analyzed below.

\section{Manipulating the agenda}

The institutional and political framework reviewed above offers many opportunities for political parties to develop competitive strategies. Minority parties in relatively extreme positions on the nationalist or the socioeconomic dimensions can manipulate the public agenda by selecting specific issues in different types of elections. As a consequence, increasing numbers of voters have chosen different parties for each level of government. The result has been the disaggregation of the previous centripetal party system and a new configuration with high polarization, especially around the bid for independence on the nationalist axis.

\section{Extreme politicians}

As we discussed above, the unplanned process of decentralization of the Spanish state at the beginning of the democratic period in the 1980s and 1990s was mostly driven by party 
competition. The more recent movements for the secession of Catalonia also derive in great measure from competitive party strategies, now in the context of vast paralysis and loss of effectiveness of the Spanish institutional and political system. Some Catalan populist politicians hold that there has been a "spontaneous" movement from the people to which the leaders responded, or that political parties go behind civil society. Yet the data reported here do not support such points of view.

There is solid evidence that most party leaders, parliamentarians, and militants of Catalonia have held more extreme positions than their voters for a long while. According to studies of many democracies, when there is centripetal party competition for a likely winning moderate position, party leaders from both the left and the right sides tend to hold more centrist positions than party militants and to some extent also than their voters. This is called the law of "linear disparity" of different groups of party members (initially formulated May 1973).

A number of surveys among the members of parliament and participants in party conferences of the main Catalan parties show that the law of linear disparity does not hold very well in this country, especially on the nationalist dimension. The leaders and activists of the Democratic Union of Catalonia (UDC) CDC, ERC, and ICV locate themselves on much more extreme Catalan positions than their voters. The PSC is an exception, which, in this case, does corroborate the rule. The available data show, in particular, that not a single CDC Member of Parliament declared to feel "as Catalan as Spanish," which was the identification of $40 \%$ of the party voters. The CDC's leaders and militants were even more radical Catalanists than the ERC voters. A polarizing effect can also be perceived toward the other side of the spectrum. The average voter sees PP and C's as much more Spanish nationalist than how the voters of these parties see themselves (Miley 2005, 2006; Baras et al. 2010; Martínez-Herrera and Miley 2010; Barrio and Juan Rodríguez 2014a, 2014b; Bermúdez and Cordero 2015; CEO 35, 2015).

The relative extremism of party leaders and militants has led to centrifugal electoral competition, in general, and high popular support for Catexit, in particular. According to survey polls, the proportion of citizens of Catalonia in favor of independence was about $15 \%$ in 2003 , more or less as it had been for decades, while an overwhelming majority supported some formula of autonomy. In contrast, the number of people having voted for independence in municipal queries in 2009-2010 or the query organized by the Generality of Catalonia in 2014 was about double, about $30 \%$, and in some polls the preferences for independence had tripled, up to $45 \%$.

There was not a similar shift in favor of only-Catalan identification, which stayed at about $20-25 \%$. The vast majority of citizens keep holding bi-national sentiments, as reported above. Changes of political preferences for independence preceded and were much bigger than changes for Catalan-only national identification. As the cause must precede the effect, changes in nationalist sentiments could not have been the main explanatory factor for political mobilization.

In general, political preferences can change much faster than cultural identities. Voting for a party or participating in a collective action are relatively low-cost decisions that people can modify in the short term. If these actions are reiterated and energetically executed, they may feed enthusiasm, a sentiment whose true sources are "hope, pride, presumption, a warm imagination, together with ignorance," according to David Hume. But, as the Scottish thinker also noted, "its fury is like that of thunder and tempest, which exhaust themselves in a little time" (Hume 1742). This implies that fast-formed new political preferences can also reverse very quickly if the political prospects that fed them do not materialize. 
In contrast, "identities" are constructed in the long term. They can be reformed and reinterpreted socially, but they tend to be much more stable. Political elites may provide specific arguments to make some national identities more desirable than others. But the completion of such cultural change also requires durable and intense mental and sentimental messages by the school and the media (Laitin 1989; Chandra 2012; Guinjoan and Rodon 2014; Tormos, Muñoz, and Hierro 2015; Muñoz and Tormos 2015).

That's why some ERC leaders, in particular, insisted on the idea that "one can be independentist without being nationalist." Even for people declaring themselves to be binational or indifferent to nationalistic issues, the supposed economic and political advantages of independence might make it attractive as a political option. Embracing the goal of a Catalan state can precede the exclusive attachment to a Catalan nation. That kind of situation can create some cognitive dissonance, which may eventually move some people having chosen independence to revise their national sentiments too. But the subsequent massive identity changes can take one or two generations to catch up.

The interpretation that self-interested party strategies have prevailed is also supported by the observation that the main public agenda does not correspond to the citizens' main concerns. In all CEO's surveys from 2010 to 2015, to the question "What do you think is the most important problem of Catalonia?" the larger group has responded "unemployment and job precariousness" (with a $46 \%$ average). "Relations Catalonia-Spain" always comes in the fourth place (with a $19 \%$ average), after "dissatisfaction with politics and politicians," and "the working of the economy."

The hypothesis that the sudden rise of support for independence was elite-driven, politically motivated, and endogenous to the political process of confrontation with the government of Spain, rather than determined by prior changes in nationalist attitudes, also fits the question that was introduced in a most recent CEO survey: "What is the main motivation for you to have become independentist in the last few years?" The most popular answer by far was: "For the attitudes and comments of the central government regarding Catalonia," with $42 \%$. This was followed by "the economy and unfair distribution of taxes," with $13 \%$, and by more than a dozen of other assorted answers with one single digit percentage support. "Catalan language and culture" was the answer of only $2.5 \%$ (CEO 34, 2015). It follows that change in the central government's "attitudes and comments" regarding Catalonia could have altered many Catalans' political preferences regarding its relations with Spain. But this hypothetical inference could not be tested.

\section{Changing the conversation}

In electoral politics, as in other human relations, what to talk about may be more important than what to say. In a multiparty system, each party can select, talk about, and give salience to those issues in which the party can expect an electoral advantage, that is, broad support from voters. At the same time, each party may try to avoid talking about those issues in which its record or its credibility put it at a disadvantage, even if the skipped issues may be important for many citizens. On many occasions, the basic strategic move is to change the subject of conversation.

As a consequence of these strategies, political parties in a campaign may not talk about the same issues, there may not be a real conversation, and public debates may become a collection of predictable monologs. Some parties may be able to force others to accept their agenda and to play in fields they would have preferred to skip. We see this in almost every electoral campaign in mature democracies. This approach can explain a large part of the recent political story of Catalonia. 
For a party to be successful in manipulating the public agenda two decisions need to be made: which issue to give salience to, and which policy proposal to promote on the issue. The two decisions are related. If there is broad policy consensus on some issues - as there was in Catalonia in the late twentieth century on moderate social-liberal economic policies, territorial autonomy, and monolingual school in the Catalan language - those issues tend to have low salience in public debate and in voters' ruminations. Parties do not discuss those issues much because they are basically in agreement about the appropriate policies to maintain and giving salience to them would not produce any partisan advantage.

In contrast, when there is a major distance in policy positions on an issue, some parties that can expect advantage for their policy proposal may prefer to argue about the issue and give it high salience. It follows that a self-interested party strategy may be to create policy distance on some issue to give it salience and expect the subsequent advantage in voters' favor. Extreme, minority parties on main policy issues may certainly try to take benefit from such a strategy. A party's extreme policy proposal - such as recentralization of the Spanish state, bilingual education, or the independence of Catalonia - can provoke confrontational responses from other parties and, thus, collective polarization on the issue. If the provocation is loud enough, it may be difficult for some parties to skip it, to avoid spending much time and resources talking about it, and to keep paying attention to more consensual issues on which they might have obtained recognition (Stokes 1963; Rabushka and Shepsle 1972; Riker 1993; Colomer and Puglisi 2005; Colomer and Llavador 2012; Balcells and Orriols 2012).

According to the location of parties in the two-dimensional policy-ideology space of Catalonia reported above, a few extreme parties were potentially interested in promoting such kinds of strategy. They were: the PP, which is extreme on the two dimensions, as it is both the most rightist and the most Spanish nationalist party; ICV, which was the most leftist party; ERC, which is the most Catalan nationalist party; as well as the CUP, which, as anti-capitalist and anti-EU, has become the most leftist party and it is very close to the most Catalan nationalist position.

In particular, the parties positioned on the left-Catalan "corner" - as for their positions in Figure 1 - can be considered double hinge or pivotal parties. They can challenge and defeat incumbents located on moderate or ambiguous positions on each of the two sides of the spectrum by introducing extreme proposals and forcing them to react. Thus, ERC was able to play games with both $\mathrm{CiU}$ on the nationalist dimension and with PSC and ICV on the left-right dimension. More recently, the CUP, which began to run in Catalan elections in 2012, tried the same game with the independentist coalition Together for Yes $(\mathrm{JxS})$ and with the leftist coalitions. The main actors of the previous centripetal consensus, CiU and PSC, were the main victims of the new centrifugal competition.

\section{The outbidding}

The process of party radicalization and subsequent polarization of the party system was more or less like this. When the electoral system allocated the PP an absolute majority of seats in the Spanish parliament from a minority of votes in 2000, Prime Minister Jose-Maria Aznar left behind its previous deals with the government of Catalonia of CiU led by Jordi Pujol and announced a "second transition." This way of action was intended to correct the "deviations" infringed by the long period of PSOE's governments to what Aznar judged to have been the initial spirit of the transition in the 1970s. He aimed, in particular, at stopping the territorial decentralization process and moving it back, as well as at strengthening the Spanish national identity and the Spanish language, Aznar's most cherished objectives. 
Then ERC, led by Josep-Lluis Carod-Rovira, offered to CiU to form a coalition in the Catalan government, with the intention to polarize the nationalist dimension against the PP. But as Pujol rejected the proposal because he expected to keep negotiating with the Spanish government, the left republicans turned to the Socialists. Subsequently, a three-party coalition government formed by PSC, ERC, and ICV and chaired by Pasqual Maragall was formed in 2003. The new government was tellingly called "Catalanist and leftist," which implied that it was as Catalanist as the previous governments of $\mathrm{CiU}$ had been, but leftist, in contrast to the prior rightist experience.

From the initial moment, at signing the so-called Pact of Tinell, the new Catalan government declared the PP and thus the Spanish government of the moment its irreconcilable adversary. The signing parties expressly excluded any governmental or parliamentary agreement with the PP, such as those previously reached by $\mathrm{CiU}$, whether in the Generality or the Spanish parliament. The first aim of the new government was to elaborate a new Statute of Autonomy of Catalonia, which a few years later was approved by the Catalan parliament and renegotiated with the Spanish government. After its modification by the Spanish parliament, it was ratified by referendum in Catalonia. But ERC, which had been the main promoter of the statute, voted against while it opened a new agenda for demands: the recognition of Catalonia as a nation, fiscal decentralization, and control of large infrastructure by the Generality.

The PP counter-reacted in kind. To start, it developed a campaign all across Spain to collect a few million signatures calling for a Spain-wide referendum against the Catalan Statute and in defense of a "single Spanish nation." Later on, the PP appealed against the Statute at the Constitutional Tribunal, where it blocked new appointments of magistrates to maintain its conservative majority and the subsequent issuance of an adverse sentence.

On the Catalan side, the re-counter-reaction for independence was developed by the strategy of making every policy disagreement an institutional issue and by canceling all other institutional alternatives to the re-centralization of the state. Specifically, the radical leaders of ERC, followed now by those of CDC, presented issues such as deficient transport infrastructures, a series of different reports on the fiscal balances between Catalonia and Spain, or the proposal of a multilingual school as if they did not leave any other way out but secession and the creation of a Catalan state. They discarded enhanced autonomy, a federal Spanish state, or a confederation of Catalonia and other territories as if they were more difficult to attain than independence was. Possible unfits with the EU were ardently denied, although the European Commission and other European high officers avowed that Catexit from Spain would mean Catexit from the EU and that an independent Catalan state should apply anew to membership in the EU.

When the CiU, now led by Artur Mas, and the PP, now led by Mariano Rajoy, regained power in the Catalan government and the Spanish government, respectively in 2010 and 2011 , they entertained themselves by outbidding each other on the nationalist dimension. Further on, CDC and ERC also outbid each other by setting sheer determination and shorter calendars for the journey to Ithaca, in Artur Mas' words. President Mas raised the bids by repeatedly asserting that when Catalonia would be independent it would have the unemployment rates of Denmark or Austria, the infrastructures of Holland, and the education model of Finland. Both parties were always prepared to offer more for less in a series of untested bluffs. When, in the Catalan election, the national policy dimension was given the highest salience, the right-wing CDC and the left-wing ERC, together with a variety of organizations and movements, temporarily merged into an electoral list for independence which gave salience to the nationalist dimension. 
On the extreme left, ICV and the CUP also had opportunities to launch innovative, radical proposals. They flourished especially since the outburst of the unexpectedly vast financial, economic, and social crisis in 2008, which made voters more prone to switching to new promises and expectations. Youth protests against austerity, economic policy, mass unemployment, lack of professional perspectives, and political degeneration proliferated along the lines of the 15-M movement in Madrid and other similar mobilizations such as "Occupy Wall Street," especially since 2011 (Anduiza, Martin, and Mateos 2013). A version of the "indignados" organized several weeks' worth of occupations of the main square in Barcelona, including street demonstrations and an assault on the parliament of Catalonia.

As mentioned, many citizens considered unemployment and the working of the economy the most important problems of Catalonia. Yet a leftist political radicalization took longer to develop than the nationalist radicalization because in the previous period, while there had been notorious ambiguities on the nationalist dimension, the main parties had approached each other around moderate centrist positions on the socioeconomic dimension. The chief role of the EU in settling the conditions and policies to recover from the crisis also made a radical left alternative more costly.

ICV had additional difficulties in becoming the main political expression of the new movement because it was marred by its Communist past, its internal divisions, and its weak coordination with the Spain-wide United Left. The new parties, We Can and the CUP, have tried to debase traditional alignments on the left-right axis and to hold the populist contention that the main dividing line is between "them and us," between those at the top and those at the bottom. They cultivate a mentality that affirms the people's virtues, rather than an ideology, a set of public policies or a left-right representation. The Catalan ICV and the Spanish We Can, together with leaders of social movements, eventually merged into joint electoral lists for the municipal, Catalan and Spanish elections in 2015 and 2016. While the independentists attained their highest point in the Catalan elections, social radicalism was rising up, especially in local and Spain-wide elections.

\section{Multiple vote}

As a consequence of partisan manipulation of several dimensions of the public agenda, considerable numbers of citizens abstain or vote for different parties at different types of elections. The so-called differential abstention was the choice of some voters mostly located on the left and Spanish side of the policy space. They tended to vote in Spanish elections, mostly for the PSOE and to a lesser extent for the PP, but they abstained in many Catalan elections. Some studies identified these voters as mostly young, immigrated from the south of Spain, monolingual in Spanish, unemployed, and with relatively low levels of education. The average number of differential abstainers in Catalonia during more than 20 years was about $13 \%$ of the electoral census, which was the highest value of all autonomous communities and about three times higher than the average.

The so-called dual vote was initially identified for three groups of voters that chose the $\mathrm{CiU}$ or, to a lesser extent, the ERC at Catalan elections, and the PSOE or, to a lesser extent, the PP at Spanish elections. They located themselves at the following three positions on the two-dimensional space: center and bi-national, center and Catalan-only, and left and bi-national. More recently, the size of the third group has declined, as the electorate has moved toward the center on the first policy axis, so that the dual vote is mostly a choice of centrist voters with slightly different allegiances on the national axis. They have crucially 
contributed to making different winners in a number of elections (the joint analysis of dual vote and differential abstention was initiated by Colomer and Padró-Solanet 1992; Colomer, Padró-Solanet, and Riba 1993; Riba 1995, and has been revised and updated by Riba 2000, 2008; Lago Peñas 2000; Medina 2015. The dual vote was examined separately by Montero and Font 1991; Pérez-Nievas Montiel and Maldonado 2000; Pérez-Nievas and Bonet 2009. The differential abstention has been discussed by Font, Contreras, and Rico 1998; Vallès 2009; Vallès and Liñeira 2014).

The differentiated electoral behavior of some voters in different types of elections is partly due to the division of powers between the multiple levels of government. The salience of either socioeconomic issues or territory-cultural ones varies in Spanish or Catalan elections, respectively. Voters can then weight each policy-ideology dimension and find themselves closer to different parties depending on which spatial axis becomes more important in their concerns (Colomer and Padró-Solanet 1992).

But voters can also be induced to cast strategic "compensation votes." On the one side, some voters with a Catalan preference can vote for a moderate Spain-wide party in Spanish elections to prevent a more radical Spanish nationalist winner. Likewise, if the likely winner or ruling party in the government of Spain holds radical Spanish nationalist positions, some moderate Catalan voters can choose a radical Catalan nationalist party in Catalan elections in order to reduce the bias in favor of Spanish nationalism in inter-institutional relations (Balcells 2007).

This may imply that some Catalan voters for the PSOE in Spanish elections are less leftist than it may seem, as it can be partly driven by the intention of having a moderate party on the nationalist dimension in the Spanish government. Also some voters for proindependence parties in Catalan elections may be less radical nationalists than it seems, as they can be encouraged to countervail the dominance of radical Spanish nationalists in the government of Spain (Pérez-Nievas Montiel and Maldonado 2000). Many of these voters may have, thus, moderate sincere preferences. But some radical parties on the Catalan side of the nationalist dimension can induce them to vote strategically in different types of elections.

For many years, there were more differential abstainers than dual voters. But it was the opposite during the 2011-2015 cycle. On one side, turnout increased in all types of elections. On the other, the dual vote has expanded into the multiple vote: in eight of the 10 largest cities of Catalonia four different parties received the highest numbers of votes in the our elections at the municipal, autonomous, state, and European levels in 20142015; in the other two cities, three different parties did; in total, six different parties were the most voted party on some election in some of the 10 largest cities.

\section{Disaggregation of the party system}

In the loosely institutionalized political systems of Catalonia and Spain, political parties were everything. And when the representation system has failed, the parties have born all the costs of the failure. Since 2010, there has been higher polarization and fragmentation of the party system, higher electoral turnout, proliferation of referendums and queries, a surge of street mobilizations, and other non-institutional forms of political action, all in parallel to the sinking of the reputation of formal political institutions.

The largest increase in political mobilization took place outside electoral and institutional processes. Two non-governmental organizations took a prominent role. Omnium Cultural was created in the 1960 s to promote the Catalan language and culture, but it recently evolved into a movement demanding self-determination for Catalonia. The 
Catalan National Assembly (ANC) was created to promote the creation of a new Catalan state; its two presidents so far were former members of ERC. Both organizations rallied several hundred thousand people in a number of street marches, chains, and demonstrations. They included one against the sentence of the Constitutional Tribunal, under the rubric "We are a nation, we decide," in 2010, and a series of them on the National Day of Catalonia with the lemmas "Catalonia, a new state of Europe" in 2012, the human chain "Catalan way to independence" in 2013, "V" as for voting for independence in 2014, and "Free way to the Catalan Republic" in 2015.

At the same time, mobilization on economic and social issues also increased dramatically. Participation in demonstrations and concentrations traditionally organized by workers' unions and political parties remained stable for many years - at around $13 \%$ of the total population. Since 2011, there have been more conflicts, and they have had a longer duration. The actions organized by new platforms, such as the 15-M, Affected by Mortgages, and others, have mobilized a total number of people equivalent to about $50 \%$ of the total population per year (not discounting people who participate in multiple actions). In total, the number of people who declared having participated in legal demonstrations during a year amounted up to 32\% (Parés 2013; CEO 36, 2015).

Massive mobilizations went together with several unlawful queries and referendums on independence. At the CUP's initiative, the town of Arenys de Munt organized the first in 2009, which was followed by more than 500 municipalities during the following year and a half. Total participation was around $30 \%$ of the electoral census.

Somehow inspired by the referendum on independence in Scotland, the government of Catalonia organized a "participative process" (which would later be declared unconstitutional) with support from the CiU, ERC, ICV, and CUP in 2014. It asked a double question regarding a Catalan state and its quality of independence. About $37 \%$ of the electoral census voted, of whom about $80 \%$ voted for a double "yes" to an independent state.

The CDC and the ERC, together with the ANC, Omnium, and the Association of Municipalities for Independence (AMI), signed a roadmap in 2015. It began with another early election to the parliament of Catalonia, the third in less than five years, which was intended to be a "plebiscite" for independence. The two candidacies explicitly supporting independence, JXS and CUP, obtained in total $47 \%$ of the votes, which was, again, about $37 \%$ of the electoral census and implied a defeat of the plebiscitarian bid. The verdict was confirmed by the results in Catalonia of the Spanish elections in 2015 and 2016. In well-institutionalized democracies, there is a trade-off in the party system between polarization and fragmentation. Either two large, polarized parties alternate in government, or a high number of parties along the ideological spectrum permit the formation of moderate coalitions around the center, the center-right, or the center-left. In Catalonia by contrast, the recent political process has brought about both more polarization and more fragmentation. The distances between the extreme parties are higher than before, while the high number of parties makes the formation of a majority difficult.

The ERC suffered a few defections when they supported President Montilla, but it reincorporated support after changing its leader to Oriol Junqueras and preparing electoral candidacies for the municipal and European elections with socialist dissidents. The ERC - as a double hinge party - was a crucial component of the candidacy for independence JxS. The ICV and EUiA also reunited and formed broader electoral candidacies, Catalonia Yes We Can (CSQEP) and In Common We Can (ECP), for the municipal, Catalan, and Spanish elections in 2015 and 2016.

In contrast, the moderate parties of the previous Catalan consensus suffered big losses. The center-left PSC, deprived of the lever of the PSOE in government and suffering from 
unfulfilled federalist promises, experienced several splits of members of parliament and lost votes on both its left and right sides.

The center-right $\mathrm{CiU}$ disbanded. The UDC suffered a split and lost parliamentary representation. The CDC ran in several electoral coalitions, lost votes on both its more Catalan and Spanish sides, and was refounded as the explicitly independentist Catalan Democratic Party (PDC). Here it may be pertinent to mention a seminal plan by Jordi Pujol, the party's founding leader and long-term Catalan president. In a youth article, he had conceived a long historical process in which the Catalans would drive a train toward full national liberation that would pass through various stations, starting with autonomy, and on the way "would lose wagons," i.e. it would go off-hooking support groups that would not be willing to continue the journey to the end. In practice, the stations have been labeled Catalanism, nationalism, sovereigntism, and independentism.

The process also ran jointly with the collapse of the reputation of the existing formal institutions. Most political parties have been eroded by a series of scandals revealing systemic corruption in the allocation of public contracts in exchange for donations and illegal party financing. The scandals and judicial prosecutions mostly affected the parties that had held the most power positions in the Spanish, Catalan, and municipal governments, which are also those that had supported the former constitutional consensus. They include former president of Catalonia Jordi Pujol and some of his relatives, several former ministers of the Generality from CDC and UDC, the former mayor of Barcelona and vice-president of the Spanish government Narcis Serra, and a number of mayors from PSC, as well as high officers of the PP including former minister and the International Monetary Funds managingdirector Rodrigo Rato and several regional presidents and mayors all across Spain. At some peak moment of scandals, President Artur Mas acknowledged that he "would not put [his] hand in the fire for anyone" (La Sexta TV 2014).

According to a most recent survey, politics inspires mistrust (up to $51 \%$ of people), political parties only serve to divide the people $(56 \%)$, all politicians are the same $(80 \%)$, whoever is in power always pursues their own personal interests $(82 \%)$, so that, all in all, most people are little or not satisfied at all with the way democracy works (81\%) (Institut de Ciencies Politiques i Socials ICPS, Sondeig d'Opinio 2014).

\section{Conclusion}

This article has focused on the process leading to the recent bid for the independence of Catalonia in the context of a vast economic, political, and social crisis of Spain. The political dynamics leading to rising levels of inter-territorial conflict has developed within a loose institutional framework which permits minority governments and offers opportunities and incentives for competitive strategies of minority and extreme party leaders. The socalled Spanish state of autonomies, which never had a consistent design, was not an equilibrium institutional formula. After about one generation, escalating inter-territorial competition gave way to a general crisis of relations between Catalonia and the Spanish state, which has intertwined with a notable crisis of the partisan system of representation of Spain. The outcome has been the dislocation of the existing autonomy without the establishment of a new alternative formula.

\section{References}

Anduiza, Eva, Irene Martin, and Araceli Mateos. 2013. "The Consequences of the 15-M Protests on Voting Choice in the 2011 Spanish General Election." Paper presented at the European Political Science Association conference, Barcelona, June 20-22. 
Balcells, Laia. 2007. “¿Es el voto nacionalista un voto de proximidad o un voto de compensación? Una nueva aproximación 'espacial' al voto en dos dimensiones." Revista Española de Ciencia Política 16: 61-88.

Balcells, Laia, and Lluís Orriols. 2012. "Party Polarisation and Spatial Voting in Spain." South European Society and Politics 17 (3): 393-409.

Baras, Montserrat, Oscar Barberà, Astrid Barrio, and Juan Rodríguez Teruel. 2010. "Estructuras de opinión de los partidos políticos y competencia multidimensional: el caso de Catalunya." Revista de Estudios Políticos 22: 49-70.

Barrio, Astrid, and Teruel Juan Rodríguez. 2014a. "Pour quelles raisons les partis politiques en Catalogne se sont-ils radicalisés? Le système des partis et la montée du souverainisme (1999-2012)." Pole Sud 40: 99-119.

Barrio, Astrid, and Teruel Juan Rodríguez. 2014b. “Does Leaders' Radicalization Make More Radical Voters? Party Elites, Outbidding Competition and Secessionism in Catalonia." Paper prepared for the workshop "The Dynamics of Nationalist Evolution in Contemporary Spain," Barcelona, September 25-26.

Bermúdez, Syra, and Guillermo Cordero. 2015. Identitats d'elits polítiques $i$ votants a Catalunya. Barcelona: Quaderns de l'ICPS, 6.

Carreras, Albert, and Xavier Tafunell. 2004. Historia Economica de la Espana Contemporanea. Barcelona: Critica.

Centre d'Estudis d'Opinió (CEO). 2015. Baròmetre d'Opinió Política, 35.

Centre d'Estudis d'Opinió (CEO). 2016. Baròmetre d'Opinió Política, 37.

Centro de Investigaciones Sociológicas (CIS). 2015a. Preelectoral de Cataluña. Elecciones autonómicas 2015. 3108.

Centro de Investigaciones Sociológicas (CIS). 2015b. Postelectoral de Cataluña. Elecciones autonómicas 2015. 3113.

Chandra, Kanchan, ed. 2012. Constructivist Theories of Ethnic Politics. New York: Oxford University Press.

Colomer, Josep M. 1985. "Una aproximacio a les arees político-electorals de Catalunya." Paper presented to the workshop "Cultura politica i participacio," Laboratory Deputation of Barcelona, June 25.

Colomer, Josep M. 1990. El arte de la manipulación política. Barcelona: Anagrama.

Colomer, Josep M. 1991. "Transitions by Agreement: Modeling the Spanish Way." The American Political Science Review 85 (4): 1283-1302.

Colomer, Josep M. 1995. Game Theory and the Transition to Democracy. The Spanish Model. Cheltenham: Edward Elgar.

Colomer, Josep M. 1998. “The Spanish 'State of Autonomies': Non-institutional Federalism.” West European Politics 21 (4): 40-52.

Colomer, Josep M. 2007. Great Empires, Small Nations. London: Routledge.

Colomer, Josep M. 2008a. "Empire-, State- and Nation-building and Deconstructing in Spain." In Multinational State Building, edited by M.-S. Darviche, and W. Genieys, 43-60. Montpellier: Pole Sud.

Colomer, Josep M. 2008b. "Spain and Portugal: Rule by Party Leadership." In Comparative European Politics, edited by Josep M. Colomer, 3rd ed., 174-206. London: Routledge.

Colomer, Josep M. 2010. "Spain: A Partisan, Non-institutional Democracy.” In Spain Towards the Americas, edited by Gabriel Castro, and Jesus M. de Miguel, 411-440. Madrid: Fundación Endesa.

Colomer, Josep M. 2016. The European Empire. Geneva: Foundation Europe Cultural.

Colomer, Josep M., and Humberto Llavador. 2012. "An Agenda-setting Model of Electoral Competition." SERIEs - Journal of the Spanish Economic Association 3: 73-93.

Colomer, Josep M., and A. Padró-Solanet. 1992. "Espacio político-ideológico y temas de campaña. El ejemplo de las elecciones autonómicas de Cataluña de 1992." Revista de Estudios Politicos 78: 131-159.

Colomer, Josep M., A. Padró-Solanet, and Clara Riba. 1993. Factors de l'abstenció electoral a la ciutat de Rubí. Barcelona: mimeo.

Colomer, Josep M., and Riccardo Puglisi. 2005. "Cleavages, Issues and Parties: A Critical Overview of the Literature." European Political Science 4: 502-520. 
Comissió d'experts. 2007. Participació, representació, transparència. Informe per a la Llei electoral de Catalunya. Barcelona: Generalitat de Catalunya, Departament de Governació i Administracions Públiques.

Downs, Anthony. 1957. An Economic Theory of Democracy. New York: Harper and Row.

Eisenstadt, S. N., and Stein Rokkan, eds. 1973. Building States and Nations, 2 vol. Beverly Hills, CA: Sage.

Enelow, James M., and Melvin J. Hinich. 1984. The Spatial Theory of Voting. Cambridge: Cambridge University Press.

Field, Bonnie. 2015. Why Minority Governments Work: Multilevel Territorial Politics in Spain. New York: Palgrave-Macmillan.

Font, Joan, Jesús Contreras, and Guillem Rico. 1998. L'abstenció en les eleccions al Parlament de Catalunya. Barcelona: Fundació Jaume Bofill - Ed. Mediterrània.

Guinjoan, Marc, and Toni Rodon. 2014. "Beyond Identities: Political Determinants of Support for Decentralization in Contemporary Spain." Regional and Federal Studies 24 (1): 21-41.

Hume, David. 1742. "Of Superstition and Enthusiasm." In Essays Moral, Political, and Literary (1742-1754). Trad. "De la superstición y el entusiasmo," in David Hume, Ensayos políticos, edited by Josep M. Colomer. Madrid: Tecnos, 1987.

Institut de Ciencies Politiques i Socials (ICPS) (Institute of Political and Social Sciences, Autonomous University of Barcelona). 2014. All Surveys and Reports. http://www.icps.cat/.

La Sexta TV. 2014. http://www.lasexta.com, 28 September 2014.

Lago Peñas, Ignacio. 2000. "Identidades duales y abstención diferencial en las Comunidades Autónomas: los casos de Catalunya, Galicia y País Vasco." Dereito 9 (2): 156-176.

Laitin, David. 1989. "Linguistic Revival: Politics and Culture in Catalonia." Comparative Studies in Society and History 31 (2): 297-317.

Linz, Juan J. 1973. "Early State-building and Late Peripheral Nationalism Against the State: The Case of Spain." In Building States and Nations, edited by S. N. Eisenstadt and Stein Rokkan, Vol. II, 32-116. Beverly Hills, CA: Sage.

Linz, Juan J. 1975. "Politics in a Multilingual Society with a Dominant World Language: The Case of Spain.” In Multilingual Political Systems: Problems and Solutions, edited by J.-G. Savard, and R. Vigneault, 367-444. Quebec: Presses de l'Universite de Laval.

Linz, Juan J. 1 ; 3. "State Building and Nation Building." European Review 1 (4): 355-369.

Martínez-Herrera, Enric, and Thomas Jeffrey Miley. 2010. "The Constitution and the Politics of National Identity in Spain." Nations and Nationalism 16 (1): 6-30.

May, John D. 1973. "Opinion Structure of Political Parties: The Special Law of Curvilinear Disparity." Political Studies 21 (2): 135-151.

Medina, Lucía. 2015. Eleccions a Catalunya. Cap a una reedició del vot dual i l'abstenció diferencial? Barcelona: Quaderns de l'ICPS, 9.

Miley, Thomas Jeffrey. 2005. "Des identités en évolution : L'exemple des Catalans dans l'Espagne contemporaine." Pôle Sud 23: 147-174.

Miley, Thomas Jeffrey. 2006. Nacionalismo y política lingüística: el caso de Catalunya. Madrid: Centro de Estudios Políticos y Constitucionales.

Montero, José Ramón, and Joan Font. 1991. "El voto dual: lealtad y transferencia de votos en las elecciones autonómicas." Estudis Electorals 10: 183-211.

Muñoz, Jordi, and Raül Tormos. 2015. "Economic Expectations and Support for Secession in Catalonia: Between Causality and Rationalization." European Political Science Review 7 (2): $315-341$.

Parés, Marc. 2013. Informe de l'estat de la democràcia a Catalunya. Barcelona: Generalitat de Catalunya, Departament de Governació i Relacions Institucionals.

Pérez-Nievas, Santiago, and Eduard Bonet. 2009. "Differential Voting for Ethno-regional Parties in Multilevel Electoral Systems." In The Multilevel Electoral System of the European Union, edited by Cees van der Eijk and Hermann Schmitt, 59-88. Manhein: University of Manheim.

Pérez-Nievas Montiel, Santiago, and Marta Fraile Maldonado. 2000. Is the Nationalist Vote Really Nationalist?: Dual Voting in Catalonia 1980-199. Madrid: Instituto Juan March de Estudios e Investigaciones, Centro de Estudios Avanzados en Ciencias Sociales, 147.

Prados de la Escosura, Leandro. 1988. De Imperio a Nacion. Crecimiento y atraso economico de Espana (1780-1930). Madrid: Alianza.

Rabushka, Alvin, and Kenneth A. Shepsle. 1972. Politics in Plural Societies. A Theory of Democratic Instability. Columbus, $\mathrm{OH}$ : Charles E. Merril. 
Riba, Clara. 1995. "Vot dual i abstenció diferencial. Tres aproximacions a l'estudi del comportament electoral a Catalunya (1982-1993)." Doctoral thesis, Universitat Autònoma de Barcelona.

Riba, Clara. 2000. "Voto dual y abstención diferencial. Un estudio sobre el comportamiento electoral en cataluña." Revista Española de Investigaciones Sociológicas 91: 59-88.

Riba, Clara. 2008. "El comportament electoral dual a Catalunya." Eines 5: 13-29.

Riker, William H., ed. 1993. Agenda Formation. Ann Arbor: The University of Michigan Press.

Rokkan, Stein. 1971. "Nation-building: A Review of Models and Approaches." In Nation-building, edited by Stein Rokkan, Kirsti Saelen, and Joan Warmbrunn, 7-38. The Hague: Mouton.

Rokkan, Stein, and Derek W. Urwin, eds. 1983. Economy, Territory, Identity: Politics of West European Peripheries. London: Sage.

Stokes, Donald E. 1963. "Spatial Models of Party Competition.” American Political Science Review 57 (2): 368-377.

Tilly, Charles, ed. 1975. The Formation of National States in Western Europe. Princeton, NJ: Princeton University Press.

Tormos, Raül, Jordi Muñoz, and Maria José Hierro. 2015. Identificació nacional: causa o conseqüència? Els efectes del debat sobre la independència en la identitat dels catalán. Papers de Treball. Barcelona: Generalitat de Catalunya, Centre d'Estudis d'Opinió.

Ucelay-Da Cal, Enric. 2014. "Catalan Nationalism, 1886-2012: An Historical Overview." Pole Sud 40: $13-28$.

Vallès, Josep M. 2009. "La abstención 'diferencial': una nota sobre los casos de Cataluña y de la Comunidad Autónoma de Madrid.” Revista Española de Ciencia Política 21: 93-105.

Vallès, Josep M., and Robert Liñeira. 2014. "Abstención diferencial en Cataluña y en la Comunidad de Madrid: explicación sociopolítica de un fenómeno urbano." Revista Española de Investigaciones Sociológicas 146 (2): 69-92. 